\author{
Dagna Siuda* \\ Magdalena Grębosz ** \\ Politechnika Łódzka
}

\title{
KREOWANIE WIZERUNKU MARKI W MEDIACH SPOŁECZNOŚCIOWYCH
}

\begin{abstract}
STRESZCZENIE
W artykule przedstawiono możliwości kreowania wizerunku marki w mediach społecznościowych. Omówiono wybrane metody komunikacji marketingowej oferowane przez media społecznościowe, wykorzystywane przez firmy do budowania i wzmacniania wizerunku marki. W artykule dokonano przeglądu literatury obcojęzycznej, wzbogaconej o polskie opracowania z zakresu teorii zarządzania marką i marketingu oraz analizę treści stron portali społecznościowych.
\end{abstract}

Słowa kluczowe: social media, marka, komunikacja marketingowa, wirtualne społeczności marek

\section{Wprowadzenie}

W obliczu rozwoju Internetu, przedsiębiorstwa coraz częściej poszukują nowych metod zarządzania marką w wirtualnej rzeczywistości, zwłaszcza w obszarze komunikacji marketingowej. Menadżerowie marek dostrzegają ogromny potencjał

\footnotetext{
* Adres e-mail: dagna siuda@p.lodz.pl

** Adres e-mail: magdalena.grebosz@p.lodz.pl
} 
mediów społecznościowych. Obecność w social media daje bowiem szansę na wykorzystanie zarówno tradycyjnych, jak i nowoczesnych form promocji.

Głównym celem referatu jest przedstawienie możliwości kreowania wizerunku marki w mediach społecznościowych. Omówiono wybrane metody komunikacji marketingowej oferowane przez media społecznościowe, wykorzystywane przez firmy do budowania i wzmacniania wizerunku marki. Cel został zrealizowany w oparciu o studia literatury obcojęzycznej, wzbogaconej o polskie opracowania z zakresu teorii zarządzania marką i marketingu oraz analizę treści stron portali społecznościowych.

\section{Rozwój Internetu i mediów społecznościowych}

Rozwój social media jest dziś możliwy przede wszystkim dzięki intensywnej ekspansji Internetu - międzynarodowej sieci pozwalającej na transmisję danych i łączącej komputery oraz inne urządzenia elektroniczne. Zgodnie z koncepcją Web 2.0., globalna sieć rozwija się dziś dzięki interaktywnej komunikacji, a nacisk położony jest na udział każdego z użytkowników w budowaniu Internetu. Od początku lat dziewięćdziesiątych XX wieku popularność Internetu rosła lawinowo. W 1993 roku internauci stanowili około 1\% populacji całego świata, w 2003 roku już 12,5\%, a w roku 2013 -38\%. W 2016 roku ponad 46\% ludzi na świecie korzystało z globalnej sieci, która liczy prawie 3,5 mld internautów (Internet Live Stats, 2016) ${ }^{1}$.

Bezpośrednim efektem wykorzystania założeń Web 2.0. jest rozwój mediów społecznościowych (social media). Według Kaznowskiego (2016) social media to „społeczne środki przekazu podlegające społecznej kontroli, które mogą być wykorzystywane na dowolną skalę, zawierające zarówno treść przekazu, jak i możliwe punkty widzenia odnoszące się do informacji”. Z kolei Kaplan i Haenlein (2010) definiują social media jako ,grupę internetowych aplikacji, opartych na ideologicznych i technologicznych fundamentach Web 2.0, pozwalających na tworzenie i wymianę treści pochodzących od użytkowników”. Mianem social media można zatem określić portale internetowe, których głównym przeznaczeniem jest umożliwienie interakcji pomiędzy ich użytkownikami. Istnieje wiele klasyfikacji mediów społecz-

1 Agencja ITU, zajmująca się zbieraniem danych o sieci, uznaje za użytkownika Internetu osobę, która ma dostęp do Internetu w miejscu swojego zamieszkania za pośrednictwem co najmniej jednego rodzaju łącza (ITU, 2009). 
nościowych. Zgodnie z podziałem zaproponowanym przez Kotlera i Kellera (2013) można wyróżnić trzy główne platformy mediów społecznościowych:

- społeczności i fora internetowe - charakteryzujące się różnorodnością form i rozmiarów, zakładane i sponsorowane zarówno przez firmy, jak i konsumentów, którzy nie mają powiązań z żadną organizacją; opierają się na dwukierunkowym przepływie treści związanych z indywidualnymi i grupowymi formami aktywności, łączącymi członków społeczności,

- blogi - mające charakter aktualizowanych dzienników zamieszczanych w Internecie; mogą być wykorzystywane do przekazywania informacji i opinii o produktach, markach i firmach, co umożliwia monitorowanie komunikatów zarówno przez firmy, jak i konsumentów,

- portale społecznościowe - służące nawiązywaniu kontaktów i wymianie treści między uży tkownikami; są wykorzystywane przez firmy nie tylko do przekazywania informacji, ale także do budowania relacji z konsumentami.

Najpopularniejszą witryną w sieci, według średniej dziennej ilości odwiedzin oraz miesięcznej ilości odsłon, jest obecnie anglojęzyczna wersja internetowej przeglądarki Google.com (Alexa, 2016). Drugie i trzecie miejsce w rankingu zajmują przedstawiciele mediów społecznościowych: służący do przesyłania i odtwarzania materiałów wideo Youtube oraz portal społecznościowy Facebook, liczący obecnie 1,75 mld użytkowników.

Sukces mediów społecznościowych polega między innymi na umożliwieniu jednostce bycia członkiem pewnej grupy, z którą dzieli wspólne wartości, normy i zainteresowania (Gangadharbhatla, 2008). Działanie to doskonale wpisuje się w teorię poczucia wspólnoty, opisywaną przez Sarasona $(1974,1986)$ oraz McMillana i Chavisa (1986) w latach 70. i 80. XX wieku. Choć od społeczności w ich rozumieniu, społeczności internetowe odróżniają się brakiem fizycznego kontaktu, to tworzące się za ich pomocą więzy są wystarczająco silne, by skłonić członków do znacznego zaangażowania w życie wirtualnej grupy, także takiej związanej z konkretną marką.

\section{Podstawy kreowania wizerunku marki}

W warunkach współczesnego rynku marka jest punktem odniesienia, który umożliwia konsumentowi ocenę zarówno materialnych cech produktu, jak i fundamentalnych niematerialnych wartości nią związanych. Dzięki marce konsument 
ma możliwość oceny stopnia identyfikacji z przedsiębiorstwem i porównania jego oferty z innymi kontrofertami na rynku. Marka jest źródłem wartości postrzeganej przez klienta i jednocześnie źródłem wartości dodanej dla przedsiębiorstwa (Grębosz, 2013). Z kolei wizerunek marki zdefiniować można jako spostrzeżenia konsumentów na temat marki, które odzwierciedlają skojarzenia zapisane w ich pamięci (Keller, 2011) lub jako „obraz firmy lub produktu, który powstaje w umyśle konsumenta na podstawie wszelkich informacji, jakie do niego docierają na temat przedsiębiorstwa czy produktu” (Dębski, 2009). Według Doyle'a (2003) wizerunek marki, czyli „zbiór przekonań o jej atrybutach i skojarzeniach”, jest kreowany na podstawie własnych doświadczeń konsumenta, źródeł osobistych (opinii przyjaciół, znajomych i innych użytkowników), źródeł publicznych oraz źródeł handlowych. W zależności od charakteru i sposobu odwoływania się do świadomości konsumenta, Doyle (2003) wyróżnia trzy typy wizerunków markowych: odwołujące się do cech produktu, aspiracji użytkowników lub doświadczeń konsumentów.

Wizerunek marki staje się w dzisiejszych czasach jednym z kluczowych czynników mających wpływ na decyzje zakupowe konsumentów. Użytkowanie produktów określonej marki może mieć znaczenie także w kontekście budowania własnego wizerunku, co jest niezwykle ważne dla osób skoncentrowanych na sobie. Ponad 1/4 przedstawicieli pokolenia $\mathrm{Y}^{2} \mathrm{w}$ Polsce jest skłonna zapłacić więcej za produkt markowy, który ma rangę kultowego. Podobne grono jest gotowe wydać więcej na produkt marki, która popiera bliski mu, szczytny cel (Odyseja Public Relations, 2015).

W kontekście rozwoju mediów społecznościowych znaczenia nabrał niematerialny wymiar marki, związany ściśle z jej osobowością, wartościami i wizerunkiem klienta docelowego. Kreowanie wizerunku marki w mediach społecznościowych jest zagadnieniem stosunkowo nowym. Jednakże jego podstawy pojawiły się

2 Pokolenie Y - młodzi ludzie, obyci z nowoczesnymi technologiami, nastawieni na rozwój i czerpanie przyjemności z życia. Pokolenie Y składa się z ludzi urodzonych w ostatnim dwudziestoleciu XX wieku (w zależności od źródła przyjmuje się daty 1977-1994 lub 1985-2000). Przedstawiono wyniki badań prowadzonych przez Odyseja Public Relations. Na potrzeby badania i raportu, jako polskich przedstawicieli pokolenia Y określono ludzi urodzonych w Polsce między rokiem 1980 a 2000.

3 Osobowość marki (brand personality) definiowana jest w literaturze przedmiotu jako zbiór charakterystycznych cech ludzkich związanych z marką i jest sposobem postrzegania marki przez kupujących oraz podstawą do formowania się silnych skojarzeń, które pozwalają rozpoznawać marki na tle innych produktów. Osobowość marki można kształtować poprzez stworzenie bohatera marki, wykreowanie wyraźnego i charakterystycznego wizerunku użytkownika marki lub poprzez wykorzystanie archetypu (Kozak i in., 2006; Styś-Hajdas, 2006). 
znacznie wcześniej, wraz z ukształtowaniem się teorii tribal marketing ${ }^{4}$, opartej na budowaniu grup, a nawet subkultur, wokół wybranych marek. Społeczność w social media można opisać jako „zbiorowość użytkowników Internetu, którzy w aktywny sposób wykorzystują tę platformę komunikacji do wymiany informacji i komunikatów związanych z ich wspólnymi zainteresowaniami, przekonaniami lub postawami” (Smektała, 2006). Wirtualna społeczność marki jest natomiast zbiorowością istniejących lub potencjalnych klientów marki, którzy współdzielą pewne zainteresowania, poglądy czy życiowe wybory, znajdujące swoje odbicie w decyzjach zakupowych. Społeczności te można określić jako internetową odmianę brand communities - społeczności skupionych wokół marki, których członkowie wchodzą w interakcje z marką oraz wymieniają się między sobą informacjami (Woisetschläger, Hartleb, Blut, 2011).

\section{Wizerunek marki w mediach społecznościowych}

Media społecznościowe umożliwiają budowanie i wzmacnianie wizerunku marki poprzez:

- prezentację elementów werbalnych marki (jak nazwa, slogan, czy jingle) zamieszczanie materiałów audio i wideo,

- prezentację elementów wizualnych marki (jak logo, symbol, grafika, kolorystyka, opakowanie oraz inne elementy wizualne związane z komunikacją),

- prezentację wartości i tożsamości marki,

- pozycjonowanie marki (zdefiniowanie rynku i grupy docelowej oraz głównych korzyści i atrybutów marki),

- realizację podstawowych celów promocyjnych (prezentacja oferty, informowanie o promocjach sprzedaży i wydarzeniach),

- prowadzenie dialogu z konsumentami (fora i portale społecznościowe),

- tworzenie więzi pomiędzy marką a jej użytkownikami oraz samymi użytkownikami.

W mediach społecznościowych marketerzy mogą kreować wizerunek marki za pomocą tzw. fanpage'ów, wokół których gromadzi się wirtualna społeczność marki. Kluczem do spełnienia tej funkcji fanpage'a jest prowadzenie go w sposób wywołujący emocje u odbiorców komunikatu. Ważne jest podkreślanie poczucia wspólnoty,

4 Tribal marketing jest określany w języku polskim także jako marketing plemienny. 
najlepiej w oparciu o wartości i idee, które konsumenci współdzielą z marką. Kolejnym celem marketerów jest zachęcenie fanów do aktywności w ramach fanpage'a, która będzie widoczna dla znajomych użytkownika. Pokazanie interakcji z marką na portalu społecznościowym funkcjonuje jako polecenie produktów danej marki. Zgodnie z zasadami tzw. marketingu szeptanego (word-of-mouth marketing), użytkownicy są bardziej skłonni nabyć produkt marki polecanej przez bliskie im osoby, niż ten reklamowany w tradycyjny sposób lub ten, którego nikt im nie polecał. Firmy mogą też zapewnić marce polecenie ich oferty, zatrudniając gwiazdy, które umieszczają na swoim profilu posty i zdjęcia dotyczące marki, często z odnośnikiem do jej fanpage'a. Takie polecenia wpływają na decyzje zakupowe zwłaszcza ludzi młodych, mogą też kreować wizerunek marki jako ekskluzywnej lub kojarzącej się z dostatnim i beztroskim życiem celebrytów. Aby zwiększyć zaangażowanie fanów i tym sposobem zwiększyć zasięg komunikatów, marketerzy stosują metodę call to action, czyli zamieszczania krótkiego komunikatu nawołującego do konkretnego działania, np. „zobacz”, „sprawdź” itp. Komunikaty często zachęcają do pozostawienia komentarza lub udostępnienia treści znajomym.

Kolejną formą komunikacji, która zwiększa zaangażowanie konsumentów i wpływa na wizerunek marki, jest oferowanie konsumentom możliwości współtworzenia wartości danej marki (Cova, Pace, Skålén, 2015). Uczestnicy wirtualnej społeczności marki mogą wyrażać swoje opinie dotyczące produktów i marki lub sugerować wprowadzenie zmian. Organizowane są też badania, w ramach których klienci mogą wybrać nowość, jaką najchętniej widzieliby w ofercie marki lub formę jej promocji. Dzięki powyższym działaniom konsumenci zrzeszeni wokół fanpage’a mają realny wpływ na to, co marka będzie oferować i w jaki sposób będzie się zmieniać.

Fanpage na portalu społecznościowym powinien odróżniać się od typowych przekazów reklamowych marki. Nie powinien także zawierać zbyt dużo suchych faktów i wiadomości pozbawionych ładunku emocjonalnego. Wielu specjalistów zaleca stosowanie postów o raczej lekkim, zabawnym stylu oraz rzadkie publikowanie tzw. poważnych treści (Moroz, 2013). Ważne jest, by marka za pomocą swojego fanpage'a odpowiednio często przypominała o swoim istnieniu, choć oczywiście zbyt częste i nachalne publikowanie treści na portalach społecznościowych może zostać przez konsumentów potraktowane jako „zaśmiecanie” strony. Dobranie odpowiedniej częstotliwości zależy od branży, z jaką związana jest marka. Jak najbar- 
dziej zrozumiałe jest, gdy kawiarnie i restauracji codziennie prezentują na swoim fanpage'u menu, jednakże w przypadku niektórych marek, których zróżnicowanie produktów jest mniejsze, publikacja podobnych postów każdego dnia może okazać się dla fanów nużąca lub wręcz irytująca.

Prowadzenie fanpage'a nie powinno być prowadzeniem monologu, lecz swoistym dialogiem z konsumentami. Nawet najlepiej przemyślana strategia i najlepsza jakość publikowanych treści nie pomogą stworzyć pozytywnego wizerunku marki, jeśli zarządzający stroną nie będą reagować na głosy fanów. Nie należy zapominać, że głównym założeniem wirtualnych społeczności marek jest wymiana informacji i tworzenie więzi między marką a konsumentami, zatem niedopuszczalne jest, by pozostawić bez odpowiedzi pytania zadane na fanpage'u. Praktycy zalecają odpowiadać nawet na posty, które teoretycznie tej odpowiedzi nie wymagają i nie stanowią typowego pytania (Karvounis, 2015).

Promocja marki za pomocą mediów społecznościowych nie generuje dużych kosztów. Opłacie podlegają tzw. posty sponsorowane lub możliwość zwiększenia liczby wyświetleń publikowanych treści, lecz samo założenie i prowadzenie fanpage'a nie wymaga dużych nakładów finansowych i może być realizowane w ramach marketingowej działalności każdej firmy.

\section{Podsumowanie}

Funkcjonując $\mathrm{w}$ turbulentnym środowisku, przedsiębiorstwa zmuszone są prowadzić aktywne działania w ramach komunikacji marketingowej. Jedną ze skutecznych metod realizacji celów rynkowych jest wyróżnianie oferty spośród innych i uzyskanie przewagi konkurencyjnej, która nie jest oparta o realizację strategii przywództwa kosztowego. Wykorzystanie działań w mediach społecznościowych w wyróżnianiu oferty pozwala budować przewagę konkurencyjną, nie tylko na podstawie cech funkcjonalnych produktów czy usług, ale także w oparciu o korzyści emocjonalne związane $\mathrm{z}$ budowaniem więzi pomiędzy konsumentami a marką oraz tworzenie wartości dodanej związanej z symboliką, relacjami z konsumentami, tożsamością użytkowników czy ich osobowością (Grębosz, Siuda, Szymański, 2016).

Media społecznościowe umożliwiają tworzenie interaktywnej przestrzeni dla konsumentów, którzy w warunkach współczesnego rynku współtworzą wartość dodaną marki, a tym samym jej wizerunek. 
Konsumenci chętnie przyłączają się do wirtualnych społeczności marek, demonstrując w ten sposób swoje sympatie i poglądy oraz kreując własny wizerunek. Wirtualne społeczności dają marketerom szansę na zaprezentowanie marki w inny sposób niż za pomocą nadużywanej reklamy tradycyjnej. Media społecznościowe oferują firmom szerokie możliwości promocji marek i kreowania ich wizerunku. Możliwe jest tworzenie fanpage'ów, w ramach których marketerzy mogą publikować informacje w formach tekstowych i graficznych oraz prowadzić swoisty dialog za pomocą „polubień”, udostępnień, komentarzy, ankiet i konkursów. Media społecznościowe pozwalają marce na nawiązanie realnej więzi z konsumentami. W czasach coraz większego narcyzmu, zwłaszcza wśród młodych ludzi, zauważenie i docenienie relacji z fanami staje się bardzo ważnym czynnikiem w budowaniu wizerunku silnej marki.

\section{Literatura}

Alexa (2016). Top sites. Pobrane z: http://www.alexa.com/topsites (24.08.2016).

Cova, B., Pace, S., Skålén, P. (2015). Firm-brand Community Value Co-creation as Alignment of Practices. European Journal of Marketing, 49 (3), 596-620.

Dębski, M. (2009). Kreowanie silnej marki. Warszawa: PWE.

Doyle, P. (2003). Marketing wartości. Warszawa: Wydawnictwo Felberg.

Gangadharbhatla, H. (2008). Facebook Me: Collective Self-esteem, Need to Belong, and Internet Self-efficacy as Predictors of the iGeneration's Attitudes Toward Social Networking Sites. Journal of Interactive Advertising, 8 (2), 5-15.

Grębosz, M. (2013). Co-branding. Koncepcja i stosowanie. Łódź: Wydawnictwa Politechniki Łódzkiej.

Grębosz, M., Siuda, D., Szymański, G. (2016). Social Media Marketing. Łódź: Wydawnictwa Politechniki Łódzkiej.

Internet Live Stats (2016). Pobrane $\mathrm{z}$ : http://www.internetlivestats.com/internet-users (12.10.2016).

ITU (2009). Manual for Measuring ICT Access and Use by Households and Individuals. Geneva.

Kaplan, A.M., Haenlein, M. (2010). Users of the World, unite! The Challenges and Opportunities of Social Media. Business Horizons, 53 (1), 59-68.

Karvounis, N. (2015). 4 Gen Y Trends that Affect Your Practice. Journal of Financial Planning, 28 (3), 16-18. 
Kaznowski, D. (2016). Social media - społeczny wymiar Internetu. W: J. Królewski, P. Sala (red.), E-marketing. Wspótczesne trendy. Pakiet startowy. Warszawa: Wydawnictwo Naukowe PWN.

Keller, K.L. (2011). Strategiczne zarzadzanie marka. Warszawa: Oficyna a Wolters Kluwer business.

Kotler, Ph., Keller, K.L. (2013). Marketing. Poznań: Dom Wydawniczy REBIS.

Kozak, A., Gózik, A., Trojanowska, A. (2006). Wpływ wizerunku marki na postrzeganie cech jej użytkownika. Marketing i Rynek, 2, 21.

McMillan, D.W., Chavis, D.M. (1986). Sense of Community: A Definition and Theory. Journal of Community Psychology, 14 (1), 6-23.

Moroz, M. (2013). Efekty budowania wizerunku marki poprzez serwisy społecznościowe - badanie opinii internautów pokolenia Y. Studia Ekonomiczne. Zeszyty Naukowe Uniwersytetu Ekonomicznego w Katowicach, 157, 123-132.

Odyseja Public Relations (2015). Milenials: cechy pokolenia Y. Pobrane z: http://www.brief. pl/artykul,2501,milenials_cechy_pokolenia_y.html (10.10.2016).

Styś-Hajdas, M. (2006). Archetyp dla marki: świętoszek czy buntownik? Marketing w Praktyce, 12, 74-76.

Sarason, S.B. (1974). The Psychological Sense of Community: Prospects for a Community Psychology. San Francisco: Jossey-Bass.

Sarason, S.B. (1986). Commentary: The Emergence of a Conceptual Center. Journal of Community Psychology, 14 (4), 405-407.

Smektała, T. (2006). Public Relations w Internecie. Wrocław: Wydawnictwo Astrum.

Woisetschläger, D.M., Hartleb, V., Blut, M. (2008). How to Make Brand Communities Work: Antecedents and Consequences of Consumer Participation. Journal of Relationship Marketing, 7 (3), 237-256. 


\title{
CREATING THE BRAND IMAGE IN SOCIAL MEDIA
}

\begin{abstract}
The article presents the possibilities of creating the brand image in social media. Selected methods of marketing communication offered by social media and used by companies to build and reinforce the brand image are also analysed. In the article the review of foreign and Polish literature concerning the theory of brand management and marketing, as well as an analysis of the content of social network sites, were applied.
\end{abstract}

Translated by Magdalena Grębosz

Keywords: social media, brand, marketing communication, virtual brand communities JEL codes: M16, M31 